\title{
Estimation of saithe Pollachius virens growth rates around the Beryl oil platforms in the North Sea: a comparison of methods
}

\author{
E. M. Mathers, D. F. Houlihan, M. J. Cunningham \\ Department of Zoology, University of Aberdeen, Tillydrone Avenue, Aberdeen AB9 2TN, Scotland, UK
}

\begin{abstract}
Six biochemical indicators of protein synthesis rate and of metabolic rate in white muscle (RNA concentration expressed as mg RNA g ${ }^{-1}$ muscle, $\mu$ g RNA $\mathrm{mg}^{-1}$ protein and mg RNA mg ${ }^{-1}$ DNA; and the activities of the enzymes citrate synthase, cytochrome oxidase and lactate dehydrogenase) were measured in individual saithe Pollachius virens caught within the Beryl Oilfield in the North Sea on 4 different occasions over a period of 1 yr. These biochemical parameters were compared with values obtained from laboratory growth experiments in order to estimate growth rates of the offshore fish. Seasonal patterns of growth rate were observed for all of these parameters and all indicated higher growth rates in the summer. Mean estimates of growth rate from RNA concentration, RNA:protein, RNA:DNA and citrate synthase activities for each group (i.e. fish caught at the same location and at the same time) were not significantly different. In addition, condition factor $(K)$, caecal-somatic index (CSI) and gall-bladder-liver index (GLI) indicated that feeding/growth rates were highest in summer and lowest in winter. Comparisons between fish caught in the Beryl Oilfield in August 1988 and a sample caught in open sea water above a submerged wreck during the same period, suggested that the fish found around the oil platforms had similar growth rates to those in the open sea
\end{abstract}

\section{INTRODUCTION}

In the North Sea, the potential biological effects of hydrocarbon pollution from oil platforms on the general health of marine life and on commercial fishery stocks is a primary concern (Dicks et al. 1988). The impact of drilling platforms in the sea is complex. There is concern about oil-coated drill-cuttings or oilbased drilling muds discharged into the sea which can lead to high concentrations of aromatic hydrocarbons in the sediments close to the platforms and it has been suggested that these may be available to fish and shellfish feeding in proximity to the platform (Massie et al. 1981). In fact, hydrocarbons have been found to accumulate in the tissues of fish and shellfish found around oil-related installations at several different locations (McGill et al. 1987, Coccheri et al. 1990, Al-Saad 1990, Parker et al. 1990).

There is evidence that many fish found in the vicinity of oil platforms are part of a resident or semi-resident marine community and that their population density decreases with increasing distance from the platform (AUMS $1987 \mathrm{a}, \mathrm{b}$ ). In a study of cod Gadus morhua and haddock Melanogrammus aeglefinnus caught in close proximity to the oil platforms of the Beryl field, significantly higher levels of hepatic aryl hydrocarbon hydroxylase were found as compared to fish of the same species caught in areas away from oil platforms (Davies et al. 1984), indicating that some hydrocarbons from drilling muds are available for fish feeding in the surrounding water.

The effect of pollutants on fish and shellfish have been considered by many workers using a variety of different approaches including: changes in swimming and feeding behaviour (Drummond et al. 1973, Luquet et al. 1983), changes in growth rate (Kearns \& Aitchison 1979), monitoring of disease prevalence in natural stocks (Bucke \& Waterman 1988), accumulation of non-nutrient metals (Pierson 1981), induction of the mixed function oxygenase system (Spies et al. 1982), 
analysis of chemical residues (Murray \& Norton 1982), and the genotoxic effect of possible mutagens (Dixon \& Clarke 1982). In many studies exposure to a pollutant has been regarded as a stressful event and specific biochemical responses to stress, such as the production of detoxification enzymes, metallothionein production and changes in the immunological defence system, have been measured (see Adams 1990, Holwerda \& Opperhuizen 1991). However, there is no evidence that either the accumulation of hydrocarbon in the flesh or the increase in the activity of enzymes to metabolise such hydrocarbons affects growth rate of fish.

The first aim of this study was to estimate the growth rates of individual saithe caught around drilling platforms within the Beryl Oilfield in the North Sea at different times of year. Pre-determined laboratory-based biochemical correlates of growth rate for saithe, which include RNA concentration (an indicator of protein synthetic activity) and enzyme activity (an indicator of metabolic energy demand) (Mathers et al. 1992), were used to estimate growth rates. In addition, condition factor (Fulton 1911), relative caecal number (Bergot et al. 1981) and relative gall bladder size (Talbot \& Higgins 1982) were measured. Seven different indicators ( 6 biochemical indicators and caecal-somatic index) were used to estimate the growth rates of the oilfield fish and comparisons were made between them. The value of using multiple indices to assess the current growth rate of fish is discussed. Secondly, the platform fish were compared with fish of the same species caught at the same time in other open sea sites (away from potential hydrocarbon pollution) using the same biochemical and physical measures. The other sites were above Transocean III, the wreck of a semisubmersible drilling rig, and Loch Ewe, a sea loch on the west coast of Scotland.

\section{MATERIALS AND METHODS}

\section{Fish collection and treatment.}

Open sea groups of fish: During 1988 and 1989, 6 fish collecting trips were made at 3 different locations. Four trips were made to the Beryl Oilfield (located at $59^{\circ} 33^{\prime}$ $\left.\mathrm{N}, 1^{\circ} 30^{\prime} \mathrm{E}\right)$, one to the waters above the wreck of Transocean III (TIII) $(8 \mathrm{~km}$ SW of the Beryl Oilfield, located at $59^{\circ} 31^{\prime} \mathrm{N}, 1^{\circ} 24^{\prime} \mathrm{E}$ ) and one to Loch Ewe in Wester Ross, Scotland. The water temperature of the Beryl Oilfield and of the area above TIII was estimated to be 6 to $7^{\circ} \mathrm{C}$ (MAFF 1981), and the temperature in Loch Ewe was $12^{\circ} \mathrm{C}$. Around the Beryl platforms and TIII, saithe Pollachius virens represented the majority of the catch ( $82 \%$ of total fish caught). Saithe were caught in Loch Ewe for comparison with the other sites. Details of catch dates and numbers, ages and weights of all saithe caught are given in Table 1 .

All fish were caught by line fishing, killed on site and samples taken within a few minutes of capture. Whole body weight was recorded and a sample of white muscle was removed from a standardised area between the dorsal fin and lateral line, immediately frozen in liquid nitrogen, transported to the laboratory in liquid nitrogen and stored at $-70^{\circ} \mathrm{C}$. The remainder of the fish were labelled and frozen at $-20^{\circ} \mathrm{C}$ for later dissection in the laboratory.

The defrosted carcasses were measured for tail-fork length and dissected to determine the weights of the pyloric caecae (the region posterior to the stomach to the end of the caecal attachment to the intestine), liver and gall bladder (including its contents).

Growth experiment fish: Saithe of between 100 and $650 \mathrm{~g}$ in weight were maintained in the laboratory for 2 to 4 wk at 8 to $12{ }^{\circ} \mathrm{C}$ with controlled levels of feeding in order to promote a wide range of growth rates. Details are given in Mathers et al. (1992).

Table 1. Pollachius virens. Numbers and weights of saithe of different ages caught in the vicinity of the Beryl oil platform in the North sea from 4 fishing trips during 1988 and 1989, above Transocean III (TIII) in August 1988 and in Loch Ewe in August 1989. All weights are given as mean $(g) \pm \mathrm{SE}$

\begin{tabular}{|c|c|c|c|c|c|c|c|c|c|c|c|c|}
\hline \multirow[t]{3}{*}{ Age } & \multicolumn{8}{|c|}{ Beryl Oil Platform } & \multirow{2}{*}{\multicolumn{2}{|c|}{$\frac{\text { TIII }}{\text { August } 1988}$}} & \multirow{2}{*}{\multicolumn{2}{|c|}{$\frac{\text { Loch Ewe }}{\text { August } 1989}$}} \\
\hline & \multicolumn{2}{|c|}{ August 1988} & \multicolumn{2}{|c|}{ October 1988} & \multicolumn{2}{|c|}{ April 1989} & \multicolumn{2}{|c|}{ August 1989} & & & & \\
\hline & $\mathrm{n}$ & Weight & $\mathrm{n}$ & Weight & $\mathrm{n}$ & Weight & & Weight & $\mathrm{n}$ & Weight & $\mathrm{n}$ & Weight \\
\hline $2+$ & & & 1 & 484.3 & 1 & 732.9 & 8 & $\begin{array}{c}738.6 \\
( \pm 105.4)\end{array}$ & 2 & $\begin{array}{c}547.6 \\
( \pm 100.5)\end{array}$ & 30 & $\begin{array}{c}224.7 \\
( \pm 1.7)\end{array}$ \\
\hline $3+$ & 7 & $\begin{array}{c}673.1 \\
( \pm 47.5)\end{array}$ & 10 & $\begin{array}{c}725.4 \\
( \pm 49.7)\end{array}$ & 23 & $\begin{array}{c}604.7 \\
( \pm 22.1)\end{array}$ & 8 & $\begin{array}{c}716.2 \\
( \pm 30.4)\end{array}$ & 11 & $\begin{array}{c}559.9 \\
( \pm 22.8)\end{array}$ & & \\
\hline $4+$ & 5 & $\begin{array}{c}934.6 \\
( \pm 98.3)\end{array}$ & 8 & $\begin{array}{c}930.9 \\
( \pm 128.1\}\end{array}$ & 6 & $\begin{array}{c}656.9 \\
( \pm 23.9)\end{array}$ & 1 & 703.5 & 5 & $\begin{array}{c}645.9 \\
( \pm 56.2)\end{array}$ & & \\
\hline $5+$ & 5 & $\begin{array}{c}1388.4 \\
( \pm 164.2)\end{array}$ & 16 & $\begin{array}{c}1254.7 \\
( \pm 94.5)\end{array}$ & 21 & $\begin{array}{c}804.7 \\
( \pm 37.0)\end{array}$ & 7 & $\begin{array}{c}1137.4 \\
( \pm 154.7)\end{array}$ & & & & \\
\hline
\end{tabular}




\section{Sample analysis.}

White muscle assays: The concentrations of RNA, DNA and protein, and the activities of the enzymes citrate synthase (EC 4.1.3.7), cytochrome oxidase (EC 1.9.3.1) and lactate dehydrogenase (EC 1.1.1.27) were determined from pieces of the frozen white muscle (Mathers et al. 1992). The RNA concentration was expressed as mg RNA g ${ }^{-1}$ muscle, $\mu \mathrm{g}$ RNA $\mathrm{mg}^{-1}$ protein and $\mathrm{mg}$ RNA $\mathrm{mg}^{-1}$ DNA. The enzyme activities were expressed as $\mu \mathrm{mol}$ substrate utilised $\mathrm{g}^{-1} \mathrm{DW} \mathrm{min}^{-1}$.

Whole body and organ measurements: Three different indices and the age of each fish were measured: (1) condition factor (K) (Fulton 1911); (2) caecalsomatic index $(\mathrm{CSI})=(C 100) / W$, where $C$ is the weight of the pyloric caecae and $W$ is the weight of the whole fish; and (3) gall bladder-liver index (GLI) $=(G 100) / L$, where $G$ is the weight of the gall bladder including its contents and $L$ is the weight of the liver.

The age of each fish was determined from examination of the sagittal zones within the otolith (Williams \& Bedford 1974).

Statistics: The effect of body size on each physical and biochemical parameter was determined using the allometric equation $Y=a X^{b}$. The value of the slope ' $b$ ' was calculated using all the wild fish and the calibration fish. When the relationship was found to be significant, ' $b$ ' was used to correct the measured values to that of the 'standard' weight of individual which was $500 \mathrm{~g}$ for this study. (The weight range of the laboratory fish was 100 to $650 \mathrm{~g}$ and for the oilfield fish the range was 200 to $2000 \mathrm{~g}$ : $500 \mathrm{~g}$ was selected as a weight common to both groups of fish.) The correlations with growth rate established for saithe (Mathers et al. 1992) were modified to represent a $500 \mathrm{~g}$ standard individual and are given in the form $y=m x+c$, where $x$ is the defined parameter and $y$ is growth rate. For all correlations with growth rate, except CSI, only growing individuals were included.

Comparisons between sets of data were made using analysis of variance and the Newman-Keuls multiple range test (Zar 1974) or the Student's $t$-test where appropriate. A $5 \%$ level of significance was used throughout.

\section{RESULTS}

The fish caught around the Alpha and Bravo platforms within the Beryl oilfield were in the age range $2+$ to $5+$ (Table 1). Seasonal variations were evident in the mean weights of the groups with a significant decline in mean weight for age classes $3+, 4+$ and $5+$ between October 1988 and April 1989 ( $p<0.05)$ followed by a significant increase in mean weight in August $1989(\mathrm{p}<0.05)$. These changes in weight are paralleled by significant changes in condition factor (see Fig. 3), therefore it is assumed that the fish actually lose weight between October and April and gain weight between April and August. For age $2+$ the sample was too small to make a comparison. The fish from above TIII were of age $2+$ to $4+$ and a comparison of these with the Beryl fish caught in August 1988 showed that the TIII fish were significantly smaller $(p<0.01)$ (Table 1). The fish caught in Loch Ewe were a younger population (all of age $2+$ ) and significantly smaller than the fish of the same age class from the Beryl August 1989 catch $(\mathrm{p}<0.001)$.

In August 1989, fish were caught around both Beryl Alpha and Beryl Bravo. A comparison of the physical and biochemical characteristics of the fish from the 2 areas of the Beryl field showed no significant differences between the Alpha and Bravo platforms (Table 2) and therefore they are treated as one location for the purposes of this study.

Table 2. Pollachius virens. Comparison between the saithe caught around Beryl Alpha $(n=18)$ and Beryl Bravo ( $n=5)$ during the same fishing trip in August 1989. Values are given as mean $\pm \mathrm{SE}$. Units of measurement are described in 'Materials and methods'

\begin{tabular}{|lcc|}
\hline Parameter & Beryl Alpha & \multicolumn{1}{c|}{ Beryl Bravo } \\
\hline Weight (g) & $816.7 \pm 60.71$ & $1034.56 \pm 226.46$ \\
Length (cm) & $41.22 \pm 1.03$ & $43.48 \pm 3.14$ \\
Condition factor & $1.14 \pm 0.02$ & $1.20 \pm 0.05$ \\
Liver-somatic index & $5.40 \pm 0.49$ & $5.95 \pm 0.76$ \\
Caecal-somatic index & $1.91 \pm 0.12$ & $1.94 \pm 0.18$ \\
RNA concentration & $0.87 \pm 0.05$ & $0.94 \pm 0.18$ \\
RNA:protein & $5.56 \pm 0.24$ & $6.45 \pm 0.86$ \\
RNA:DNA & $0.802 \pm 0.06$ & $0.853 \pm 0.08$ \\
Lactate dehydrogenase & $0.834 \pm 0.05$ & $0.854 \pm 0.06$ \\
Cytochrome oxidase & $8.99 \pm 1.14$ & $10.31 \pm 4.80$ \\
& & \\
\hline
\end{tabular}

\section{Seasonal variations}

Seasonal variations were evident for all the biochemical and physical indices with the highest values found in August and the lowest in April in most cases (Figs. 1 to 3). The exceptions were GLI, which increased in winter because bile accumulated as feeding was reduced, protein:DNA, which remained constant throughout the year and lactate dehydrogenase activity, which peaked in autumn. No significant differences were observed between Beryl and T3 in August 1988, or between Beryl and Loch Ewe in August 1989.

The measured values (for all parameters) of the summer-caught oilfield and open sea fish were within the relevant ranges found for the fed laboratory fish in all cases. This is demonstrated for condition factor and RNA: protein in Fig. 4. We are therefore confident that the laboratory-based correlations can be used to estimate the growth rates of the open sea fish. 

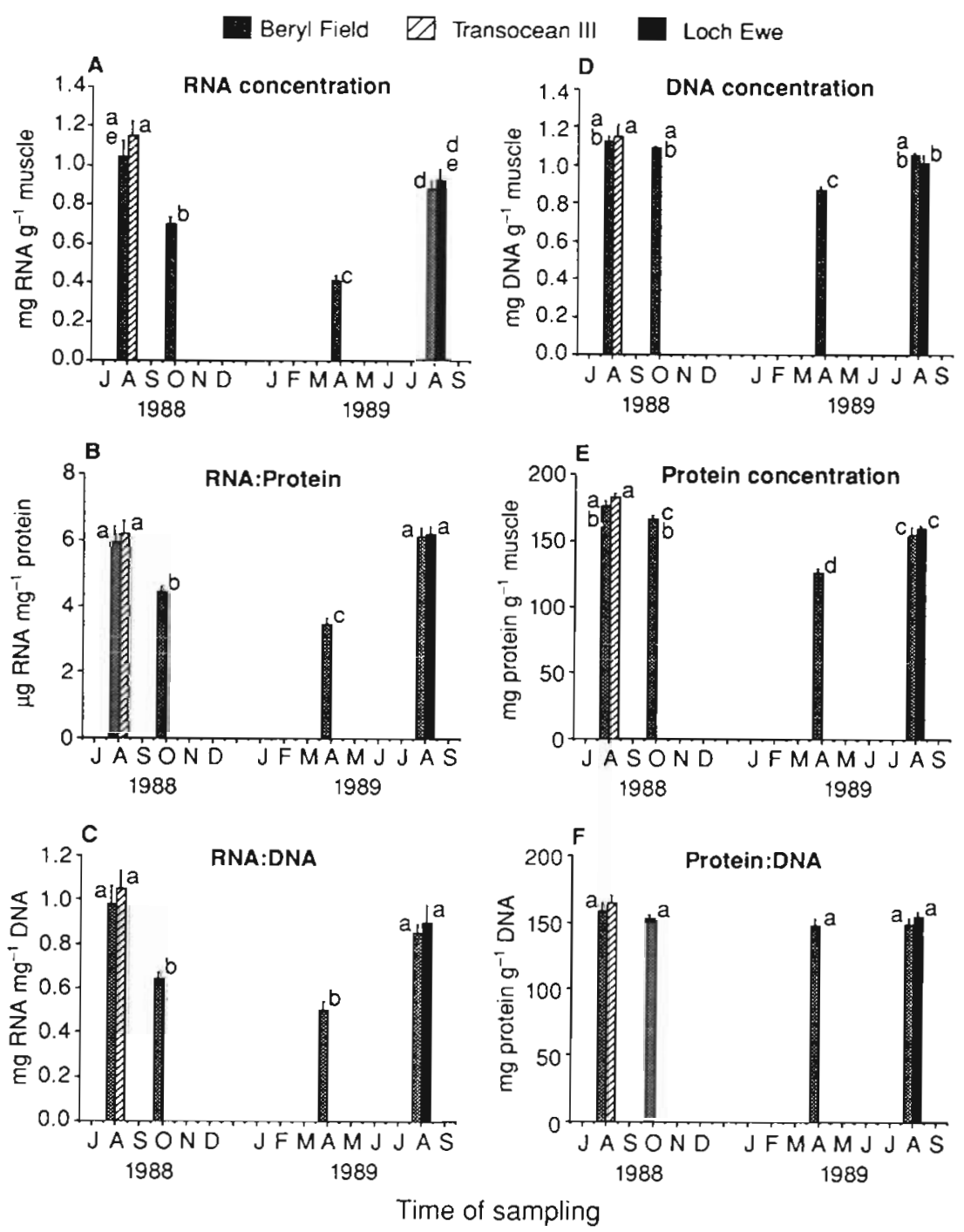

Fig. 1. Pollachius virens. Seasonal variations in (A) $\mathrm{mg}^{\mathrm{RNA} \mathrm{g}} \mathrm{g}^{-1}$ muscle, (B) $\mu \mathrm{g}$ RNA $\mathrm{mg}^{-1}$ protein, (C) $\mathrm{mg}_{\mathrm{RNA}} \mathrm{mg}^{-1}$ DNA, (D) mg DNA g ${ }^{-1}$ muscle, (E) $\mathrm{mg}$ protein $\mathrm{g}^{-1}$ muscle and $(F) \mathrm{mg}$ protein $\mathrm{mg}^{-1}$ DNA for the saithe caught around the Beryl oil platforms and those from Transocean III in August 1988 and Loch Ewe in August 1989

\section{Correlations with growth rate}

Correlations with growth rate for RNA concentration, RNA : protein, RNA : DNA, CO activity, CS activity and $\mathrm{LDH}$ activity for growing laboratory maintained saithe were determined as described in Mathers et al. (1992). In addition, a significant correlation was found between CSI for both fed and starved laboratory individuals described by the equation:

$$
\text { CSI }=0.512 \text { growth rate }\left(\% \mathrm{~d}^{-1}\right)+1.61
$$

where $n=27, r=0.567$ and $p<0.01$

No correlation was found between growth rate and either $K$ or GLI.

\section{Effect of body size}

The relationships with body size and each growth correlate for the pooled group of growth experiment, Beryl Field, TIII and Loch Ewe saithe were determined (Table 3). All the data were used and no distinction was made between the variable feeding/growth rates of the offshore fish. Significant relationships were found for RNA concentration, RNA: protein and RNA:DNA but not for the enzyme activities or CSI. Correction factors (as determined in Table 3) for body size were applied as described above (see 'Materials and methods') and the corrected correlations with growth rate were calculated (Table 4).

\section{Growth rate estimates of wild saithe populations}

The 7 different growth correlates established above were used to estimate the growth rates of individual wild fish. The mean estimates ( \pm SE) were calculated for each method and the 7 values for each group are given in Table 5. A seasonal pattern of growth rate is evident with the highest values in August and the lowest values in April. This is in agreement with the changes observed in Figs. 1 to 3.

For each sampling time, comparisons were made between the 7 different methods of estimating growth rate using analysis of variance and the Newman-Keuls test. Four out of the 7 indices used gave similar estimates of growth rate. The 3 expressions of RNA concentration gave mean growth rate estimates which were not significantly different in all cases except Beryl in April 1989, and the estimates from CS activity were in agreement with the estimates from RNA concentration in all cases. The other 3 indices agreed with RNA concentration in some instances: CO activity gave a similar estimate in 2 cases (Beryl, October 1988 and Loch Ewe, August 1989), while estimates from LDH activity were in agreement with RNA concentration in 1 case (TIII, August 1988) and CSI in 2 cases (TIII, August 1988 and Loch Ewe, August 1989). For Beryl in April 1989, most growth rate 

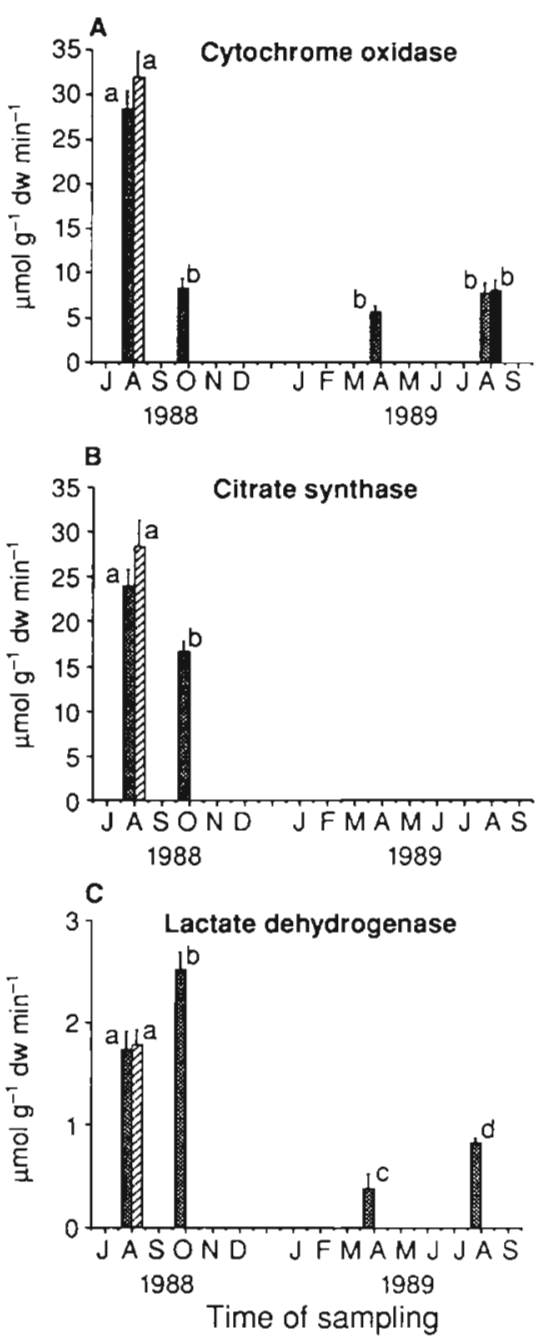

Fig. 2. Pollachius virens. Seasonal variations in the activities of the enzymes (A) cytochrome oxidase, (B) citrate synthase and (C) lactate dehydrogenase for the saithe caught around the Beryl oil platforms and those from Transocean III in August 1988 and Loch Ewe in August 1989. Shading as in Fig. 1

estimates were negative (RNA concentration, CO, LDH and CSI) indicating that the fish were losing weight.

Comparisons were also made between sites sampled at the same time. The growth rates estimates of the fish caught from Beryl and TIII in August 1988 were not significantly different for any of the methods used for estimating growth rate (Table 5). Comparison between Beryl and Loch Ewe in August 1989 showed that the growth rate estimates from RNA concentration, RNA: protein and RNA: DNA were significantly lower for the Loch Ewe fish, while the $\mathrm{CO}$ and CSI estimates showed no significant difference (Table 5). However, when fish of the same age class $(2+)$ were compared, no significant differences were found except for RNA: DNA.
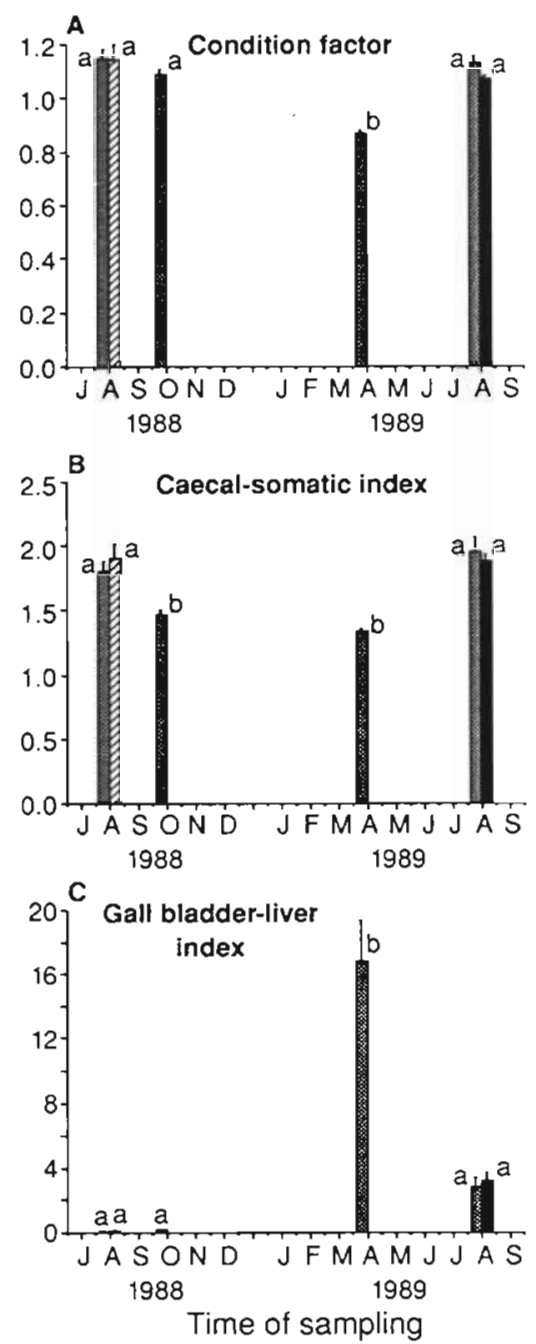

Fig. 3. Pollachius virens. Seasonal variations in (A) condition factor, (B) caecal-somatic index and (C) gall bladder-liver index for the saithe caught around the Beryl oil platforms and those from Transocean III in August 1988 and Loch Ewe in August 1989. Shading as in Fig. 1

\section{DISCUSSION}

Ribonucleic acid (RNA) is concerned with the transfer of the genetic code from DNA and the synthesis of new proteins, and the amount of RNA within a tissue is directly related to its protein synthesis requirements (Houlihan et al. 1989). In this study we have shown that the RNA concentration in white muscle does vary with season: slow growth or weight loss in winter is accompanied by low RNA concentrations while higher growth rates in summer are supported by higher RNA concentrations. The ratios of RNA:DNA and RNA: protein have also been used to express RNA concentration in order to overcome the problems of change in water content or differences in cell number which may occur with changes in growth rate (Bulow 1970, 

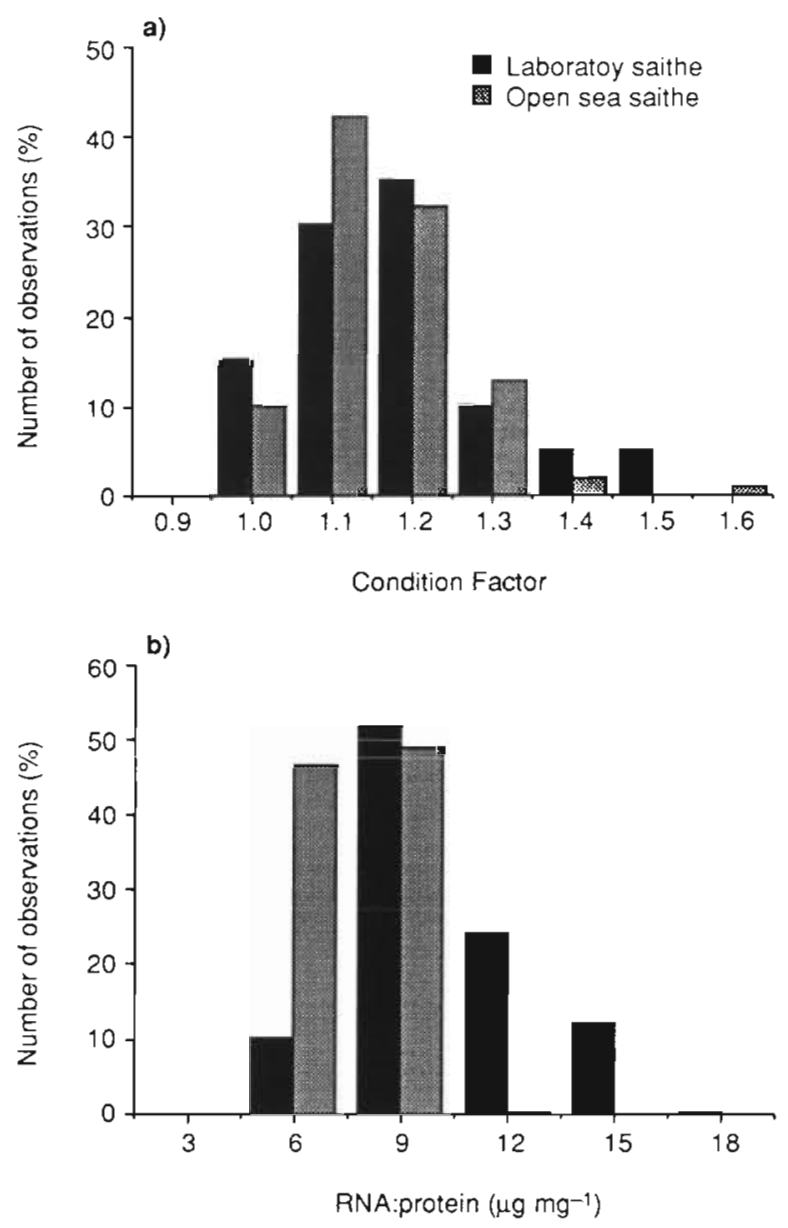

Fig. 4. Pollachius virens. Distribution of measured values for (A) condition factor $K$ and (B) RNA : protein for the fed laboratory fish and all the August sampled oil field and open sea fish

Robinson \& Ware 1988). RNA:DNA and RNA: protein ratios varied significantly with season, but variation in the DNA and protein concentrations with season were also significant, although the ratio between the 2 remained constant. This would indicate that the ratios of RNA:DNA and RNA: protein may be subject to seasonal variation as a result of changes in tissue composition with feeding status in addition to the changes in RNA activity and concentration associated with protein synthesis rates. The RNA content of a tissue or whole animal may therefore be better described in relation to dry weight.

The activity of any enzyme within a tissue is related to its requirement and therefore to the metabolic rate of that tissue. In the present study, seasonal patterns in enzyme activity were observed corresponding to periods of slow or negative winter growth and higher rates of growth in the summer. Cytochrome oxidase activity in fish around Beryl and Transocean III in August 1988 and from Beryl and Loch Ewe in August 1989, were not significantly different. However, there was a significant difference between the CO activity between 1988 and 1989 (Fig. 3). The same is true for LDH activity and this disagrees with the values obtained for all the physical indices and for RNA concentration. It was noted at dissection that most of the fish caught in August 1989 had large amounts of food in the stomach and intestines, indicating recent feeding. Enzyme activities have been shown to respond to changes in feeding level with reduced activity during starvation (Moon \& Johnston 1980, Sullivan \& Somero 1983) and increased activity post feeding (Goolish \& Adelman 1988). The increase in enzyme activity is associated with an increase in protein synthesis but it would seem that immediately after feeding there is a period of elevated enzyme activity similar to the compensatory growth described for RNA activity by Miglavs \& Jobling (1989). This post-feeding elevation in enzyme activity may also affect the activity of CS but data are not available.

In previous studies various physical indicators have been used individually to assess the condition and sea-

Table 3. Pollachius virens. Regressions of log parameter $y$ on log body weight $x$ for all the saithe from the Beryl field, Transocean III, Loch Ewe and the laboratory. Measurements were made on white muscle and the parameters included are RNA concentration (RNA; mg RNA $g^{-1}$ tissue), the ratio of RNA concentration to protein concentration (RNA: protein; $\mu \mathrm{g} \mathrm{RNA} \mathrm{mg}^{-1}$ protein), the ratio of RNA concentration to DNA concentration (RNA: DNA; mg RNA mg $^{-1}$ DNA), the activities of the enzymes citrate synthase

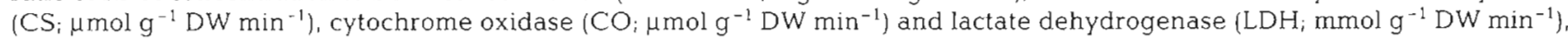
and the caecal-somatic index (CSI; \% total wt). NS: not significant

\begin{tabular}{|lcrcc|}
\hline Parameter & Regression & $\mathrm{n}$ & $\mathrm{r}$ & $\mathrm{p}$ \\
\hline RNA & $\log y=-0.257 \log x+0.577$ & 220 & 0.362 & $<0.001$ \\
RNA: protein & $\log y=-0.283 \log x+1.468$ & 220 & 0.488 & $<0.001$ \\
RNA: DNA & $\log y=-0.288 \log x+0.700$ & 214 & 0.460 & $<.001$ \\
CS & $\log y=-0.148 \log x+1.719$ & 72 & 0.134 & NS \\
CO & $\log y=0.101 \log x+0.568$ & 176 & 0.052 & NS \\
LDH & $\log y=0.852 \log x-2.514$ & 137 & 0.087 & NS \\
CSI & $\log y=-0.260 \log x+2.377$ & 176 & 0.170 & \\
\hline
\end{tabular}


Table 4. Pollachius virens. Weight corrected geometric mean regression equations of growth rate $x$ and parameter $y$ for RNA concentration, nucleic acid ratios, enzyme activities and CSI for the growth experiment saithe. Abbreviations are as in Table 3. Data is modified from Mathers et al. (1992) to a $500 \mathrm{~g}$ standard fish size

\begin{tabular}{|c|c|c|c|c|}
\hline Parameter & Regression & $\mathrm{n}$ & $r$ & $\mathrm{p}$ \\
\hline RNA & $y=1.700 x-0.724$ & 38 & 0.683 & $<0.001$ \\
\hline RNA: protein & $y=0.274 x-0.556$ & 38 & 0.694 & $<0.001$ \\
\hline RNA: DNA & $y=1.314 x-0.304$ & 38 & 0.477 & $<0.01$ \\
\hline CS & $y=0.063 x-0.468$ & 14 & 0.734 & $<0.01$ \\
\hline $\mathrm{CO}$ & $y=0.104 x-0.329$ & 16 & 0.628 & $<0.01$ \\
\hline $\mathrm{LDH}$ & $y=0.193 x+0.338$ & 12 & 0.677 & $<0.02$ \\
\hline CSI & $y=1.160 x-1.770$ & 27 & 0.595 & $<0.01$ \\
\hline
\end{tabular}

sonal growth patterns of groups of fish (e.g. Bulow 1970, Bergot et al. 1981, Buckley 1984). Adams \& McLean (1985) have shown for largemouth bass Micropterus salmoides that various indices, including condition factor and liver-somatic index, may not reflect changes in growth or weight until several weeks or months following a change in environmental conditions and would therefore be unsuitable for measuring instantaneous growth rates. The GLI is useful as an indicator of recent feeding (Talbot \& Higgins 1982): when fish are actively feeding the gall bladder is continuously excreting bile into the intestines and is small in proportion to the liver, but when fish are not feeding bile is stored and the gall bladder becomes larger in proportion to the liver. Caecal number was found to be related to body size found for rainbow trout Salmo gairdneri Richardson (now Oncorhynchus mykiss) (Bergot et al. 1981) and it was proposed that the number of caecae present could influence the digestion of food and indirectly the growth rate of trout. In a recent study significant differences in caecal weight have been found between fed and starved salmon (Pringle et al. 1992). In the present study CSI was found to correlate with short-term growth rate for feeding and starving fish (from laboratory experiments) and was the only physical index to do so. Growth rate estimates from CSI agreed with those form RNA concentration in only 2 cases: it may be that the time course of adaptation of the CSI to feeding rates may be different to the RNA response.

Consideration of the problems outlined above leads to the conclusion that the most reliable method for estimating growth rate is RNA content expressed either as a concentration within the muscle or as a ratio. There is increasing evidence that protein synthetic capacity and aerobic capacity may be linked because of the energy cost of protein synthesis (Goolish \& Adelman 1987. Houlihan et al. 1992) and in the present study the activities of the aerobic enzymes CO and CS were in agreement with the RNA concentrations in most cases. However, LDH activity did not correspond with RNA concentration, CO activity or CS activity. In fact, LDH activity has been shown to be associated with feeding frequency (Sullivan \& Somero 1983) and with swimming activity (Childress \& Somero 1990) rather than growth.

Table 5. Pollachius virens. Growth rate estimates for saithe caught at the open sea sites using each of the parameters found to correlate with growth rate. The values given are mean $\% \mathrm{~d}^{-1} \pm \mathrm{SE}$. Where the growth rate was found to be less than $0 \% \mathrm{~d}^{-1}$ the growth rate estimate is given as 'negative' because fish losing weight as a result of starvation were found not to show any relationship with growth rate for all parameters except CSI

\begin{tabular}{|c|c|c|c|c|c|c|c|}
\hline Site/date & $\begin{array}{l}\text { RNA: protein } \\
\quad\left(\mu g \mathrm{mg}^{-1}\right)\end{array}$ & $\begin{array}{l}\text { RNA: DNA } \\
\left(\mathrm{mg} \mathrm{mg}^{-1}\right)\end{array}$ & $\begin{array}{c}\text { RNA } \\
\left(\mathrm{mg} \mathrm{g}^{-1} \mathrm{WW}\right)\end{array}$ & $\begin{array}{c}\mathrm{CS} \\
\left(\mu \mathrm{mol} \mathrm{g}{ }^{-1}\right. \\
\left.\mathrm{DW} \mathrm{min}^{-1}\right)\end{array}$ & $\begin{array}{c}\mathrm{CO} \\
\left(\mu \mathrm{mol} \mathrm{g}^{-1}\right. \\
\left.\mathrm{DW} \mathrm{min}^{-1}\right)\end{array}$ & $\begin{array}{c}\mathrm{LDH} \\
\left(\mathrm{mmol} \mathrm{g}^{-1}\right. \\
\left.\text { DW min }{ }^{-1}\right)\end{array}$ & $\begin{array}{c}\text { CSI } \\
(\% \text { body wt) }\end{array}$ \\
\hline Beryl, Aug 1988 & $1.71 \pm 0.23^{\text {d. }}$ & $1.60 \pm 0.28^{a} \cdot$ & $1.50 \pm 0.20^{\mathrm{ab}}$ & $1.17 \pm 0.16^{\mathrm{ac}} \cdot$ & $3.98 \pm 0.32^{\mathrm{d}} \cdot$ & $0.58 \pm 0.11^{b c}$. & $0.36 \pm 0.13^{c, \cdot}$ \\
\hline TIII, Aug 1988 & $1.43 \pm 0.17^{\mathrm{a}} \cdot$ & $1.41 \pm 0.24^{\mathrm{a}_{4} \cdot}$ & $1.58 \pm 0.50^{\mathrm{a}}$ & $1.60 \pm 0.24^{\mathrm{a}^{*} \cdot}$ & $4.90 \pm 0.54^{\mathrm{b} .}$ & $0.61 \pm 0.08^{a^{*}}$ & $0.66 \pm 0.17^{\mathrm{a}} \bullet$ \\
\hline Beryl, Oct 1988 & $0.81 \pm 0.08^{\mathrm{ab}}$ & $0.52 \pm 0.08^{\mathrm{a}}$ & $0.58 \pm 0.08^{\mathrm{a}}$ & $0.57 \pm 0.10^{\circ}$ & $0.52 \pm 0.14^{\mathrm{a}}$ & $1.10 \pm 0.11^{\mathrm{b}}$ & $-0.28 \pm 0.06^{c}$ \\
\hline Beryl, Apr 1989 & $0.31 \pm 0.09^{\mathrm{a}}$ & $0.02 \pm 0.12^{a}$ & negative & not determined & negative & negative & $-0.52 \pm 0.05^{b}$ \\
\hline Beryl, Aug 1989 & $1.51 \pm 0.15^{\mathrm{a}}$ & $1.09 \pm 0.13^{\mathrm{db}}$ & $1.18 \pm 0.13^{\mathrm{ab}}$ & not determined & $0.68 \pm 0.22^{b .4}$ & $0.01 \pm 0.03^{c}$ & $0.64 \pm 0.19^{b c . \#}$ \\
\hline Loch Ewe, Aug 1989 & $0.62 \pm 0.06^{a}$ & $0.34 \pm 0.09^{\mathrm{a}}$ & $0.32 \pm 0.09^{\mathrm{a}}$ & $0.56 \pm 0.08^{\mathrm{a}}$ & $0.51 \pm 0.20^{\mathrm{a}}$ & not determined & $0.54 \pm 0.09^{\mathrm{a}, \#}$ \\
\hline
\end{tabular}


Other factors which may have an effect on the growth rate estimates include temperature and exposure to extrinsic chemicals. Changes in water temperature have been found to affect the growth rate of several species of fish, with an increase in temperature resulting in higher growth rates (Buckley 1982, 1984, Rafael \& Braunbeck 1988). There is also evidence that fish growing at the same rate have higher tissue RNA concentrations at lower temperatures (Houlihan et al. 1992). In the North Sea, fish found around oil platforms are subject to little change in temperature with season (normally $\pm 1{ }^{\circ} \mathrm{C}$; MAFF 1981), while fish from the inshore water of Loch Ewe are subject to a wider range of temperature with season. Therefore the growth rate estimates for the Loch Ewe fish at $12{ }^{\circ} \mathrm{C}$ are possibly under estimates as the calibration curve was calculated from data collected at $8{ }^{\circ} \mathrm{C}$.

The RNA concentration within tissues of fish has been shown to be reduced as a result of exposure to low pH (Mudge et al. 1977), cadmium (Kearns \& Aitchison 1979) and hydrogen cyanide (Barron \& Adelman 1984). Controlled exposure of laboratory maintained Atlantic cod Gadus morhua to low concentrations of crude oil resulted in poor feeding, reduction in condition factor, reduction in some organ-somatic indices and the delay of spermeation (Kiceniuk \& Khan 1987). In the present study, no direct assessment of the effect of possible exposure to hydrocarbons or other chemical pollutants was made. However, it is worth noting that none of the fish caught around the oil platforms were seen to be diseased or to have skin lesions, and the organ somatic indices were not significantly different from those fish maintained in the laboratory.

Comparison of the fish from the Beryl Field with those from Transocean III in August 1988 showed no significant differences. Comparison of Beryl with Loch Ewe in August 1989 showed no significant differences in the measured values for each index, but values for estimated growth rate for the fish around the oil platform were higher than those from the inshore loch after the effect of body size was taken into account. This emphasises the need to compare like with like, and illustrates the difficulties that can arise when comparing populations of differing size and age structure. To conclude this comparison, it does not appear from this study that the saithe found in the Beryl Oilfield are growing less well than saithe at the other sites sampled.

It is necessary to accept that when sampling fish or any other animal from its natural environment, there are many factors affecting the growth of that fish at the time of capture which may or not be the same as factors affecting the rate of growth several days or weeks prior to capture, all of which lead to inevitable uncertainties in the interpretation of any individual physical or biochemical measurement. It would seem reasonable to suggest that, although each individual index has its merits, the use of multiple indices to assess the growth rate of wild fish may give a more reliable value which can take into account a large range of environmental influences. The present study demonstrates firstly the usefulness of both biochemical and physical measurements as indicators of seasonal growth patterns of fish, and secondly the usefulness of biochemical indices as measures of growth rate at the time of capture. The physical indices provided a picture of the growth and feeding status of the fish for several weeks prior to capture, and combining the information from all the physical indices provides a better interpretation of the recent growth and feeding status of each fish, or group of fish, than using only one index. The biochemical measurements indicated the metabolic activity of the white muscle at the time of capture, with RNA concentration reflecting the protein synthetic activity and the enzyme activities reflecting the energy demand. Indeed, it was observed that high RNA concentrations coincided with high levels of aerobic enzyme activity. In a theoretical situation where a group of fish had been feeding under stable conditions for several weeks, the biochemical measurements would all indicate the same rate of growth and the physical indices would reflect that rate of growth. However, the rate of growth of fish is variable and can be affected by many natural environmental factors and by extrinsic pollutants (as discussed above). Rapid changes in the concentrations and activities of such substances as RNA, protein, citrate synthase and cytochrome oxidase would cause changes in the metabolic rate, and hence the growth rate, of the fish within a very short time of exposure, but these changes would not immediately be reflected in the physical indices. Thus it is possible to imagine a fish which had been growing well prior to exposure to some adverse factor which would then exhibit low RNA concentrations and low levels of enzyme activity indicative of a reduction in growth rate, coupled with high values for $K$ and CSI. Therefore the use of multiple indices can provide a better assessment of the growth rate of an open sea fish at its time of capture.

Acknowledgements. This study was supported by funding from Mobil North Sea Ltd. We thank $M$. Irvine and $A$. Cunningham of Aberdeen University Marine Studies Ltd. for their assistance with the collection of the samples from around the oil platforms and TIII.

\section{LITERATURE CITED}

Adams, S. M. (ed.) (1990). Biological indicators of stress. American fisheries society symposium 8, Bethseda, Maryland. Am. Fish. Soc., Bethesda

Adams, S. M., McLean, R. B. (1985). Estimation of largemouth bass, Micropterus salmoides Lacepede, growth using the liver somatic index and physiological variables. J. Fish Biol. 26: 111-126 
Al-Saad, H. T. (1990). Distribution and sources of aliphatic hydrocarbons in fish from the Arabian Gulf. Mar. Pollut. Bull. 21: 155-157

AUMS (Aberdeen University Marine Studies Ltd) (1987a). Fish activity around North Sea oil platforms. Report to the United Kingdom Offshore Operator's Association Ltd., London

AUMS (Aberdeen University Marine Studies Ltd) (1987b). Fish activity around North Sea oil platforms, Phase II: a survey of Transocean III. Report to the United Kingdom Offshore Operator's Association Ltd, London

Barron, M. G., Adelman, I. R. (1984). Nucleic acid, protein content and growth of larval fish sub-lethally exposed to various toxicants. Can. J. Fish. Aquat. Sci. 41: 141-150

Bergot, P., Blanc, J. M., Escaffre, A. M. (1981). Relationship between number of pyloric caecae and growth in rainbow trout (Salmo gaidneri Richardson). Aquaculture 22: $81-96$

Bucke, D., Watermann, B. (1988). Effects of pollutants on fish. In: Salomons, W., Bayne, B. L., Duursma, E. K., Forstner, U. (eds.) Pollution of the North Sea: an assessment. SpringerVerlag, Berlin, p 612-623

Buckley, L. J. (1982). Effects of temperature on growth and biochemical composition of larval winter flounder, Pseudopleuronectes americanus. Mar. Ecol. Prog. Ser. 8: $181-186$

Buckley, L. J. (1984). RNA-DNA ratio: an index of larval fish growth in the sea. Mar. Biol. 80: 291-298

Bulow, F. J. (1970). RNA-DNA ratios as indicators of recent growth rates of a fish. J. Fish. Res. Bd Can. 27: 2343-2349

Childress, J. J., Somero, G. N. (1990). Metabolic scaling: a new perspective on scaling of glycolytic enzyme activities. Am. Zool. 30: 161-173

Cocchieri, R. A., Arnese, A., Minicucci, A. M. (1990). Polycyclic aromatic hydrocarbons in marine organisms from Italian central Mediterranean coasts. Mar. Pollut. Bull. 21: 15-18

Davies, J. M. Bell, J. S., Houghton, C. (1984). A comparison of the levels of hepatic aryl hydrocarbon hydroxylase in fish caught close to and distant from North Sea oil fields. Mar. environ. Res. 14: 23-45

Dicks, B., Bakke, T., Dixon, I. M. T. (1988). Oil exploration and production and oil spills. In: Salomons, W., Bayne, B. L., Duursma, E. K., Forstner, U. (eds.) Pollution of the North Sea: an assessment. Springer-Verlag, Berlin, p. 524-537

Dixon, D. R., Clarke, K. R. (1982). Sister chromatid exchange: a sensitive method for detecting damage caused by exposure to environmental mutagens in the chromosomes of adult Mytilus edulis. Mar. Biol. Lett. 3: 163-172

Drummond, R. A., Spoor, W. A., Olson, G. F. (1973). Some shortterm indicators of sublethal effects of copper on brook trout, Salvelinus fontinalis. J. Fish. Res. Bd Can. 30: 698-701

Fulton, T. W. (1911). The sovereignty of the sea. Blackwood, London, Edinburgh

Goolish, E. M., Adelman, I. R. (1987). Tissue-specific cytochrome oxidase activity in largemouth bass: the metabolic costs of feeding and growth. Physiol. Zool 69(4): 454-464

Goolish, E. M., Adelman, I. R. (1988). Tissue-specific allometry of an aerobic respiratory enzyme in a large and small species of cyprinid (Teleostei). Can. J. Zool. 66: 2199-2208

Holwerda, D. A., Opperhuizen, A. (eds.) (1991). Physiological and biochemical approaches to the toxicological assessment of environmental pollution. Comp. Biochem. Physiol. $100 \mathrm{C}$ (special issue). Pergammon Press, Oxford

Houlihan, D. F., Hall, S. J., Gray, C. (1989). Effects of protein turnover in cod. Aquaculture 79: 103-110
Houlihan, D. F., Mathers, E., Foster, A. (1992). Biochemical correlates of growth rate in fish. In: Rankin, J. C., Jensen, F. B. (eds.) Fish ecophysiology. Chapman \& Hall, London, in press

Kearns, P. K., Aitchison, G. J. (1979). Effects of trace metals on the growth of yellow perch (Perca flavescens) as measured by RNA:DNA ratios. Environ. Biol. Fish. 4: 383-387

Kiceniuk, J. W., Khan, R. A. (1987). Effect of petroleum hydrocarbons on Atlantic cod, Gadus morhua, following chronic exposure. Can. J. Zool. 65: 490-494

Luquet, P., Cravedi, J. P., Choubert, G., Tulliez, J., Bories, G. (1983). Long-term ingestion by rainbow trout of saturated hydrocarbons: effects of n-paraffins, pristane and dodecylcyclohexane on growth, feed intake, lipid digestibility and canthaxanthin deposition. Aquaculture 34: 15-25

McGill, A. S., Mackie, P. R., Howgate, P., McHenery, J. G. (1987). The flavour and chemical assessment of dabs (Limanda limanda) caught in the vicinity of the Beatrice oil platform. Mar. Pollut. Bull. 18: 186-189

MAFF (1981). Atlas of the seas around the British Isles. Ministry of Agriculture, Fisheries and Food, Southhampton

Massie, L. C., Ward, A. P., Bell, J. S., Saltzmann, H. A. (1981). The levels of hydrocarbons in water and sediments in selected areas of the North Sea, and the assessment of their biological effect. Counc. Meet. C.M.-ICES int. Counc. Explor. Sea/E:44

Mathers, E. M., Houlihan, D. F., Cunningham, M. J. (1992). Nucleic acid concentrations and enzyme activities as correlates of growth rate of saithe, Pollachius virens: Growth rate estimates of open sea fish. Mar. Biol. 112: $363-369$

Miglavs, I., Jobling, M. (1989). Effects of feeding regime on food consumption, growth rates and tissue nucleic acids in juvenile Arctic charr, Salvelinus alpinus, with particular respect to compensatory growth. J. Fish Biol. 34: 947-957

Moon, T. W., Johnston, I. A. (1980). Starvation and the activities of glycolytic and gluconeogenic enzymes in the skeletal muscles and liver of the plaice, Pleuronectes platessa. J. comp. Physiol. (Sect. B) 136: 31-38

Mudge, J. E., Dively, J. L., Neff, W. H., Anthony, A. (1977). Interrenal histochemistry of acid exposed brook trout, Salvelinus fontinalis Mitchell. Gen. comp. Endocr. 31: 208-215

Murray, A. J., Norton, M. G. (1982). The field assessment of effects of dumping wastes at sea: 10 analyses of chemical residues in fish and shellfish from selected coastal regions around England and Wales. Fish. Res. Tech. Rep. Minist. Agric. Fish. Fd, Directorate Fish. Res., Lowestoft, Suffolk 69: $1-42$

Parker, J. G., Howgate, P., Mackie, P. R., McGill, A. S. (1990). Flavour and hydrocarbon assessment of fish from gas fields in the southern North Sea. Oil chem. Pollut. 6: $263-277$

Pierson, K. B. (1981). Effect of zinc exposure on the growth, sexual maturity, reproduction and bioaccumulation of the guppy, Poecilia reticulata. Can. J. Fish. Aquat. Sci. 38: 23-31

Pringle, G. M., Houlihan, D. F., Callanan, K. R., Mitchell, A. I., Houghton, G., Raynard, R. (1992). Digestive enzyme levels and histopathology of pancreas disease in farmed Atlantic salmon (Salmo salar). Comp. Biochem. Physiol. 102A: 759-768

Rafael, J., Braunbeck, T. (1988). Interacting effects of diet and environmental temperature on biochemical parameters in the liver of Leuciscus idus melanotus (Cyprinidae: Teleostei). Fish Physiol. Biochem. 5: 9-19 
Robinson, S. M. C., Ware, D. M. (1988). Ontogenetic development of growth rates in larval Pacific herring, Clupea harengus pallasi, measured with RNA:DNA ratios in the strait of Georgia, British Columbia. Can. J. Fish. Aquat. Sci. 45: 1422-1429

Spies, R. B., Felton, J. S., Dillard, L. (1982). Hepatic MFO in California flatfish are increased in contaminated environments and by oil and PCB ingestion. Mar. Biol. 70: 117-127

Sullivan, K. M., Somero, G. (1983). Size- and diet-related variations in enzymic activity and tissue composition in

This article was submitted to the editor the sablefish, Anoplopoma fimbria. Biol. Bull. 164 $315-326$

Talbot, C.. Higgins, P. J. (1982). Observations on the gall bladder of the juvenile Atlantic salmon, Salmo salar $L_{\text {., }}$ in relation to feeding. J. Fish Biol. 21: 663-669

Williams, T., Bedford, B. C. (1974). The use of otoliths for age determination. In: Bagenal, T. B. (ed.) Proc. internat. symp. on ageing of fish, Univ. of Reading (July, 1973). Unwin Bros., Surrey, p. 114-123

Zar, J. H. (1974). Biostatistical analysis. Prentice-Hall, Englewood Cliffs

Manuscript first received: February 25, 1992

Revised version accepted: July 23, 1992 